NURSING HISTORY

AND HUMANITIES

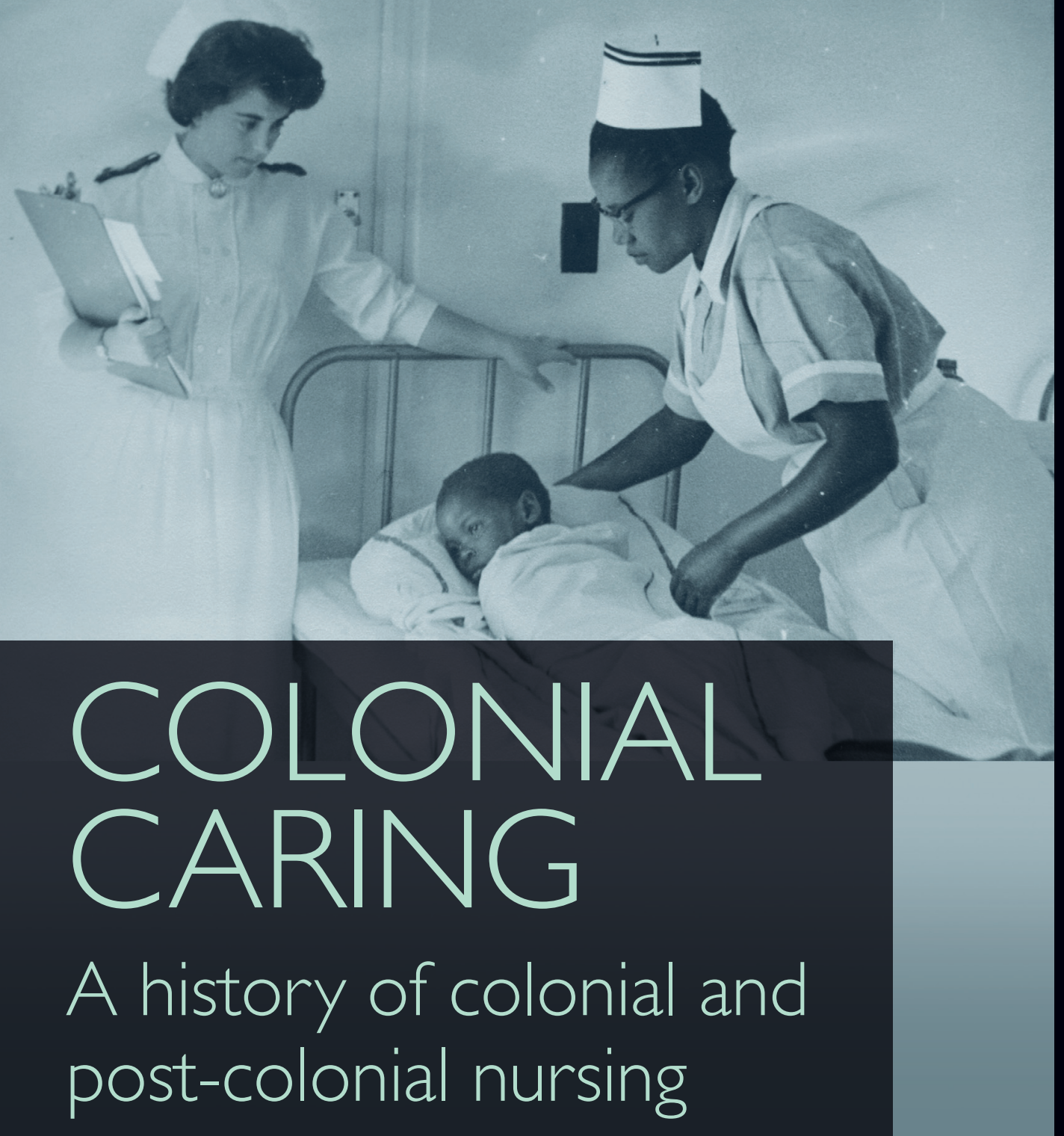

Edited by

Helen Sweet and Sue Hawkins 


\section{Blank page}


Colonial caring

\section{MANCHESTER 1824}

Manchester University Press

Helen Sweet and Sue Hawkins - 9781526129369 


\section{Nursing History and Humanities}

This series provides an outlet for the publication of rigorous academic texts in the two closely related disciplines of Nursing History and Nursing Humanities, drawing upon both the intellectual rigour of the humanities and the practice-based, real-world emphasis of clinical and professional nursing.

At the intersection of Medical History, Women's History and Social History, Nursing History remains a thriving and dynamic area of study with its own claims to disciplinary distinction. The broader discipline of Medical Humanities is of rapidly growing significance within academia globally, and this series aims to encourage strong scholarship in the burgeoning area of Nursing Humanities more generally.

Such developments are timely, as the nursing profession expands and generates a stronger disciplinary axis. The MUP Nursing History and Humanities series provides a forum within which practitioners and humanists may offer new findings and insights. The international scope of the series is broad, embracing all historical periods and including both detailed empirical studies and wider perspectives on the cultures of nursing.

Previous titles in this series:

Mental health nursing: The working lives of paid carers in the nineteenth and twentieth centuries

Edited by Anne Borsay and Pamela Dale

One hundred years of wartime nursing practices, 1854-1954

Edited by Jane Brooks and Christine E. Hallett

'Curing queers': Mental nurses and their patients, 1935-74

Tommy Dickinson

Histories of nursing practice

Edited by Gerard M. Fealy, Christine E. Hallett and

Susanne Malchau Dietz

Who cared for the carers? A history of the occupational health of nurses, 1880-1948

Debbie Palmer 


\section{COLONIAL CARING}

\section{A history of colonial and post-colonial nursing}

EDITED BY HELEN SWEET AND SUE HAWKINS

Manchester University Press 
Copyright (c) Manchester University Press 2015

While copyright in the volume as a whole is vested in Manchester University Press, copyright in individual chapters belongs to their respective authors.

This electronic version has been made freely available under a Creative Commons (CCBY-NC-ND) licence, which permits non-commercial use, distribution and reproduction provided the author(s) and Manchester University Press are fully cited and no modifications or adaptations are made. Details of the licence can be viewed at https://creativecommons.org/licenses/by-nc-nd/3.0/

Published by Manchester University Press Altrincham Street, Manchester M1 7JA www.manchesteruniversitypress.co.uk

British Library Cataloguing-in-Publication Data A catalogue record for this book is available from the British Library Library of Congress Cataloging-in-Publication Data applied for

ISBN 9780719099700 hardback

First published 2015

The publisher has no responsibility for the persistence or accuracy of URLs for any external or third-party internet websites referred to in this book, and does not guarantee that any content on such websites is, or will remain, accurate or appropriate.

Typeset by Out of House Publishing 